\title{
Development of a one-run real-time PCR detection system for pathogens associated with bovine respiratory disease complex
}

\author{
Mai KISHIMOTO'), Shinobu TSUCHIAKA ${ }^{1,2)}$, Sayed Samim RAHPAYA ${ }^{1,2)}$ \\ Ayako HASEBE ${ }^{3)}$, Keiko OTSU ${ }^{3)}$, Satoshi SUGIMURA ${ }^{4)}$, Suguru KOBAYASHI ${ }^{4)}$, \\ Natsumi KOMATSU ${ }^{4)}$, Makoto NAGAI ${ }^{1,6)}$, Tsutomu OMATSU ${ }^{1,2)}$, Yuki NAOI ${ }^{1)}$, \\ Kaori SANO ${ }^{1)}$, Sachiko OKAZAKI-TERASHIMA ${ }^{1)}$, Mami OBA ${ }^{1)}$, Yukie KATAYAMA ${ }^{11}$, \\ Reiichiro SATO ${ }^{5)}$, Tetsuo ASAI ${ }^{2)}$ and Tetsuya MIZUTANI ${ }^{1,2) *}$ \\ 1) Research and Education Center for Prevention of Global Infectious Diseases of Animals, Tokyo University of \\ Agriculture and Technology, 3-5-8 Saiwai, Fuchu, Tokyo 183-8509, Japan \\ 2)The United Graduate School of Veterinary Sciences, Gifu University, 1-1 Yanagito, Gifu 501-1193, Japan \\ 3) Gifu Central Livestock Hygiene Service Center, 4-2-22 Imamine, Gifu, Gifu 500-8388, Japan \\ 4)Institute of Agriculture, Tokyo University of Agriculture and Technology, 3-5-8 Saiwai, Fuchu, Tokyo 183-8509, \\ Japan \\ ${ }^{5)}$ Azabu University, School of Veterinary Medicine, 1-17-71 Fuchinobe, Chuo-ku, Sagamihara, Kanagawa \\ 252-5201, Japan \\ 6) Faculty of Bioresources and Environmental Sciences, Ishikawa prefectural University, 1-308, Suematsu, \\ Nonoichi-shi, Ishikawa 921-8836, Japan
}

\section{J. Vet. Med. Sci.}

79(3): 517-523, 2017

doi: $10.1292 / j v m s .16-0489$

Received: 22 September 2016 Accepted: 23 December 2016 Published online in J-STAGE: 8 January 2017
ABSTRACT. Bovine respiratory disease complex (BRDC) is frequently found in cattle worldwide. The etiology of BRDC is complicated by infections with multiple pathogens, making identification of the causal pathogen difficult. Here, we developed a detection system by applying TaqMan real-time PCR (Dembo respiratory-PCR) to screen a broad range of microbes associated with $B R D C$ in a single run. We selected 16 bovine respiratory pathogens (bovine viral diarrhea virus, bovine coronavirus, bovine parainfluenza virus 3 , bovine respiratory syncytial virus, influenza $D$ virus, bovine rhinitis A virus, bovine rhinitis $B$ virus, bovine herpesvirus 1, bovine adenovirus 3 , bovine adenovirus 7, Mannheimia haemolytica, Pasteurella multocida, Histophilus somni, Trueperella pyogenes, Mycoplasma bovis and Ureaplasma diversum) as detection targets and designed novel specific primer-probe sets for nine of them. The assay performance was assessed using standard curves from synthesized DNA. In addition, the sensitivity of the assay was evaluated by spiking solutions extracted from nasal swabs that were negative by Dembo respiratory-PCR for nucleic acids of pathogens or synthesized DNA. All primer-probe sets showed high sensitivity. In this study, a total of 40 nasal swab samples from cattle on six farms were tested by Dembo respiratoryPCR. Dembo respiratory-PCR can be applied as a screening system with wide detection targets.

KEY WORDS: bovine respiratory disease complex, diagnosis, taqMan real-time PCR

Bovine respiratory disease complex (BRDC) is one of the most prevalent cattle diseases, causing large economic losses in the cattle industry worldwide. For example, BRDC is estimated to account for $70-80 \%$ of all feedlot cattle morbidity and $40-50 \%$ of all cattle mortality, resulting in a loss of greater than US \$500 million per year in the United States [16, 22]. In Japan, number of illness in the statistics mutual aid for livestock owners in 2014 reported by the Ministry of Agriculture, Forestry and Fisheries indicate that respiratory diseases accounted for $23 \%$ of illness in cattle (http://www.maff.go.jp/j/tokei/kouhyou/katiku_kyosai/) (in Japanese). Despite considerable research and attempts to manage hygiene to prevent BRDC, these measures have had a limited effect on reducing the impacts of this disease [29].

One of the difficulties in investigation and prevention of BRDC is its multi-factorial etiology, based on host interactions with multiple pathogens, such as virus and bacteria, including mycoplasma. The primary viral infection sometimes results in clinical symptoms, and it was exacerbated by secondary infections with bacterial pathogens [10]. Stressors, such as transportation, and host factors, such as nutritional status, raise the risk and severity of BRDC [17,28]. Viruses, which are commonly associated with

*Correspondence to: Mizutani, T., Research and Education Center for Prevention of Global Infectious Diseases of Animals, Tokyo University of Agriculture and Technology, 3-5-8 Saiwai, Fuchu, Tokyo 183-8509, Japan. e-mail: tmizutan@cc.tuat.ac.jp

(C2017 The Japanese Society of Veterinary Science

This is an open-access article distributed under the terms of the Creative Commons Attribution Non-Commercial No Derivatives (by-nc-nd) License. (CC-BY-NC-ND 4.0: https://creativecommons.org/licenses/by-nc-nd/4.0/) 
BRDC, include bovine viral diarrhea virus (BVDV), bovine coronavirus (BCoV), bovine parainfluenza virus 3 (BPIV-3), bovine respiratory syncytial virus (BRSV), bovine herpesvirus 1 (BHV-1), and bovine adenovirus 3 (BAdV 3) and 7 (BAdV 7) [12, 28]. In addition, a metagenomic approach to BRDC in cattle recently revealed that several other viruses may be involved in BRDC, such as influenza D virus (IDV), bovine rhinitis A virus (BRAV) and bovine rhinitis B virus (BRBV) [13, 23]. Mannheimia haemolytica, Pasteurella multocida, Histophilus somni, Trueperella pyogenes and Mycoplasma bovis are bacteria consistently associated with BRDC $[1,11]$. Ureaplasma diversum has also been isolated from BRDC cattle [8]. Infection with each single pathogen does not necessarily result in appearance of symptoms, but complex infections with a variety of pathogens, including the indigenous agents, develop severe conditions. Such multiple pathogens infection make it difficult to identify the etiology of BRDC rapidly.

To adopt appropriate measures, such as vaccination or hygiene management, and to minimize the economic loss of BRDC, it is necessary to quickly, accurately and comprehensively detect multiple pathogens present in varying proportions in each herd. Serological tests, pathogen isolation and PCR-based tests are currently available to diagnose BRDC in laboratories [7]. Most tests are based on a one assay-one pathogen approach, lacking comprehensiveness to use for rapid diagnosis. We previously developed a system to detect microbes in bovine diarrhea by TaqMan real-time PCR (Dembo diarrhea-PCR), permitting the simultaneous screening of 19 pathogens associated with diarrhea [31]. Advantages of TaqMan real-time PCR are high sensitivity, high specificity and simple operation. The objective of this study was to develop a system based on TaqMan real-time PCR that can detect 16 pathogens, including viruses and bacteria, associated with BRDC in one run (Dembo respiratory-PCR), similar to Dembo diarrheaPCR.

\section{MATERIALS AND METHODS}

\section{Primer and probe design}

A total of 16 primer-probe sets were used to detect pathogens that certainly or possibly cause BRDC. Each primer-probe set was designed to detect a single target pathogen. As shown in Table 1, seven primer-probe sets were adopted from a previously reported real-time PCR assay [2, 18, 20, 21, 26, 32, 33]. The remaining nine primer-probe sets were newly designed in this study. To design these primers and probes, nucleotide sequences obtained from GenBank of a target pathogen were aligned, and then, primers and probes were selected using PrimerQuest software (Integrated DNA Technologies, Inc., Coralville, IA, U.S.A.). Accession numbers of sequences used for primer-probe design are listed in Supplemental Table 1. The specificities of primers and probes were checked by BLAST search. In addition, as described in a previous report, a primer-probe set for bovine $\beta$-actin was as an internal control of RNA/DNA extraction and PCR reaction [31, 32]. TaqMan probes had 6-FAM (6-carboxy-fluorescein) fluorescent reporter molecules at the 5' ends and TAMRA (6-carboxy-tetra-methyl-rhodamine) quencher molecules at the 3' ends. TaqMan probes targeting BPIV-3 and $U$. diversum contained 6-FAM at the $5^{\prime}$ ends and MGB (minor groove binder) and NFQ (non fluorescent quencher) at the 3' ends. Primers and probes were custom-synthesized at Sigma-Aldrich (Sigma Aldrich, St. Louis, MO, U.S.A.) and MGB probes at Applied Biosystems (Applied Biosystems, Foster City, CA, U.S.A.). The information on primers and probes is outlined in Table 1.

\section{DNA and RNA extraction}

Nucleic acids were extracted using the following four commercial kits according to the manufacturers' instructions. Virus, bacteria and negative nasal swab sample used for the sensitivity test were centrifuged at $14,000 \times \mathrm{g}$ for 5 min. Viral DNA and RNA were extracted from supernatants, using a High Pure Viral Nucleic Acid Kit (Roche Diagnostics GmbH, Mannheim, Germany), with an elution volume of $25 \mu l$. Bacterial DNA was extracted from cell pellets, using a QIAamp UCP Pathogen Mini Kit (Qiagen, Hilden, Germany) with a sample volume of $1 \mathrm{~m} l$ and elution volume of $50 \mu l$. In extraction of clinical samples, RNA was extracted using a QIAamp Viral RNA Mini Kit (Qiagen) with a sample volume of $140 \mu l$ and elution volume of $60 \mu l$. DNA was extracted using a QIAamp DNA Mini Kit (Qiagen) with a sample volume of $200 \mu l$ and elution volume of $200 \mu l$. The extracted DNA and RNA were stored at $-80^{\circ} \mathrm{C}$ until it was tested by real-time PCR.

\section{Real-time PCR}

A One Step PrimeScript RT-PCR Kit (Perfect Real Time) (TaKaRa Bio, Otsu, Japan) was used to detect viral RNA, and Premix Ex Taq (Perfect Real Time) (TaKaRa Bio) was used to detect viral and bacterial DNA. Real-time PCR assays were conducted in the same reaction conditions, including reaction mix components and thermal cycling, as those used in the Dembo diarrhea-PCR [31]. Fluorescent signal data were analyzed using an automatic quantification algorithm in LightCycler Nano Software 1.1 (Roche Diagnostics $\mathrm{GmbH}$ ), and the parameters of analysis were as follows: exclude early cycle=7, minimum relative amplifications $=0$, and minimum amplification quality $=5$.

\section{Validation of real-time PCR performance using synthesized DNA}

To verify the sensitivity, linearity and efficiency of the real-time PCR assay, the limit of detection (LOD), correlation coefficient $\left(\mathrm{R}^{2}\right)$ and PCR efficiency (E) were determined from standard curves. Standard curves were obtained, and the LOD, $\mathrm{R}^{2}$ and $\mathrm{E}$ were calculated as described previously [31].

\section{Sensitivity test for nasal swabs}

In a previous study, nasal swab samples appeared to contain a PCR inhibitor that yielded false negative results [25]. To evaluate 
Table 1. The primer-probe sets used for the detection system

\begin{tabular}{|c|c|c|c|c|}
\hline Target pathogen & Target gene & Primer/Probe sequence $5^{\prime}-3^{\prime}$ & $\begin{array}{l}\text { Product } \\
\text { size (bp) }\end{array}$ & $\begin{array}{c}\text { Reference } \\
\text { No. }\end{array}$ \\
\hline \multirow{3}{*}{ Bovine viral diarrheal virus } & $5^{\prime}$ UTR & F GGGNAGTCGTCARTGGTTCG & 190 & [20] \\
\hline & & R GTGCCATGTACAGCAGAGWTTTT & & \\
\hline & & P FAM-CCAYGTGGACGAGGGCAYGC-TAMRA & & \\
\hline \multirow[t]{3}{*}{ Bovine coronavirus } & Nucleocapsid & F GGACCCAAGTAGCGATGAG & 90 & This study \\
\hline & & $\mathrm{R}$ GACCTTCCTGAGCCTTCAATA & & \\
\hline & & P FAM-ATTCCGACTAGGTTTCCGCCTGG-TAMRA & & \\
\hline \multirow[t]{3}{*}{ Bovine parainfluenza virus 3} & matrix $(\mathrm{M})$ protein & F TGTCTTCCACTAGATAGAGGGATAAAATT & 90 & {$[18]$} \\
\hline & & R GCAATGATAACAATGCCATGGA & & \\
\hline & & P FAM-ACAGCAATTGGATCAATAA-NFQ-MGB & & \\
\hline \multirow[t]{3}{*}{ Bovine respiratory syncytial virus } & Nucleocapsid & F GCAATGCTGCAGGACTAGGTATAAT & 124 & [2] \\
\hline & & $\mathrm{R}$ ACACTGTAATTGATGACCCCATTCT & & \\
\hline & & P FAM-ACCAAGACTTGTATGATGCTGCCAAAGCA-TAMRA & & \\
\hline \multirow[t]{3}{*}{ Influenza D virus } & PB1 & F CAGCTGCGATGTCTGTCATAAG & 83 & This study \\
\hline & & R ACAAATTCGCAGGGCCATTA & & \\
\hline & & P FAM-AATGGACTTTCTCCTGGGACTGCT-TAMRA & & \\
\hline \multirow[t]{3}{*}{ Bovine rhinitis A virus } & 3Dpol & F CACCTGAACTATGGACTTGG & 171 & This study \\
\hline & & R CACGGCCTCAATCATCTG & & \\
\hline & & P FAM-GACGTGGACTGGCACCAGTTTGC-TAMRA & & \\
\hline \multirow[t]{3}{*}{ Bovine rhinitis B virus } & 3Dpol & F AACGCGATTGTGTCCTAGGG & 112 & This study \\
\hline & & R GCCACTGAGGTTAGCTTCTC & & \\
\hline & & P FAM-CTGTCCTTTGCACGGCGTGG-TAMRA & & \\
\hline \multirow[t]{3}{*}{ Bovine herpesvirus 1} & $\mathrm{gE}$ & F CAATAACAGCGTAGACCTGGTC & 85 & {$[32]$} \\
\hline & & R GCTGTAGTCCCAAGCTTCCAC & & \\
\hline & & P FAM-TGCGGCCTCCGGGCTTTACGTCT-TAMRA & & \\
\hline \multirow[t]{3}{*}{ Bovine adenovirus 3} & Hexon & F ATTACCAGCGTCAACCTCTAC & 121 & This study \\
\hline & & $\mathrm{R}$ CCGCCGAGAGATAGTCATTAAA & & \\
\hline & & P FAM-TCCACTTTGGAAGCTATGCTCCGC-TAMRA & & \\
\hline \multirow[t]{3}{*}{ Bovine adenovirus 7} & Hexon & F CRAGGGAATAYYTGTCTGAAAATC & 87 & [33] \\
\hline & & R AAGGATCTCTAAATTTYTCTCCAAGA & & \\
\hline & & P FAM-TTCATCWCTGCCACWCAAAGCTTTTTT-TAMRA & & \\
\hline \multirow[t]{3}{*}{ Mannheimia haemolytica } & sodA & F ATTAGTGGGTTGTCCTGGTTAG & 144 & This study \\
\hline & & R GCGTGATTTCGGTTCAGTTG & & \\
\hline & & P FAM-CTGAACCAACACGAGTAGTCGCTGC-TAMRA & & \\
\hline \multirow[t]{3}{*}{ Pasteurella multocida } & kmt-1 & F GGGCTTGTCGGTAGTCTTT & 148 & This study \\
\hline & & R CGGCAAATAACAATAAGCTGAGTA & & \\
\hline & & P FAM-CGGCGCAACTGATTGGACGTTATT-TAMRA & & \\
\hline \multirow[t]{3}{*}{ Histophillus somni } & 16S-rRNA & F AAGGCCTTCGGGTTGTAAAG & 93 & This study \\
\hline & & R CCGGTGCTTCTTCTGTGATTAT & & \\
\hline & & P FAM-CGGTGATGAGGAAGGCGATTAG-TAMRA & & \\
\hline \multirow[t]{3}{*}{ Trueperella pyogenes } & plo-Pyolysin & F ATCAACAATCCCACGAAGAG & 99 & This study \\
\hline & & $\mathrm{R}$ TTGCAGCATGGTCAGGATAC & & \\
\hline & & P FAM-TCGACGGTTGGATTCAGCGCAATA-TAMRA & & \\
\hline \multirow[t]{3}{*}{ Mycoplasma bovis } & oppD & F TCAAGGAACCCCACCAGAT & 71 & [26] \\
\hline & & R AGGCAAAGTCATTTCTAGGTGCAA & & \\
\hline & & P FAM-TGGCAAACTTACCTATCGGTGACCCT-TAMRA & & \\
\hline \multirow[t]{3}{*}{ Ureaplasma diversum } & 16S-rRNA & F CATTAAATGATGTGCCTGGGTAGTAC & 61 & [21] \\
\hline & & R CCCCGTCAATTCCGTTTG & & \\
\hline & & P FAM-TTCGCAAGAATGAAAC-NFQ-MGB & & \\
\hline \multirow[t]{3}{*}{$\beta$-ACTIN } & Actin & F AGCGCAAGTACTCCGTGTG & 96 & [32] \\
\hline & & R CGGACTCATCGTACTCCTGCTT & & \\
\hline & & P FAM-TCGCTGTCCACCTTCCAGCAGATGT-TAMRA & & \\
\hline
\end{tabular}

F: Forward primer; R: Reverse primer; P: Probe.

PCR inhibition by nasal swab components, a positive control nucleic acid was added to negative samples after nucleic acids extraction as previously described [3, 24]. Nasal swabs collected from clinically healthy cattle that were confirmed to be negative by Dembo respiratory-PCR for all target pathogens were tested. These swabs were suspended in phosphate-buffered saline (-) to make 10\% emulsion. Isolated strains of BPIV-3 strain BN-1 (AB770484), BRSV strain NMK-7, BRAV strain H-1 (JN936206), M. haemolytica strain N791 (bovine/Japan/1979), P. multocida strain TS-8, H. somni strain 23N2359, T. pyogenes strain 42 and 
Table 2. Performance of sensitivity tests based on nasal swab samples

\begin{tabular}{|c|c|c|c|}
\hline \multirow{2}{*}{ Type of spiked nucleic acid } & \multirow{2}{*}{ Pathogens } & LOD & Reproducibility \\
\hline & & (/reaction) & CV (\%) \\
\hline \multirow[t]{6}{*}{ Viral DNA or RNA $\left(\mathrm{TCID}_{50}\right)$} & Bovine viral diarrheal virus & 1 & 0.67 \\
\hline & Bovine parainfluenza virus 3 & 100 & 2.25 \\
\hline & Bovine respiratory syncytial virus & 0.1 & 0.30 \\
\hline & Bovine rhinitis A virus & 0.1 & 1.30 \\
\hline & Bovine herpesvirus 1 & 10 & 0.09 \\
\hline & Bovine adenovirus 7 & 1 & 0.66 \\
\hline \multirow[t]{5}{*}{ Bacterial DNA (CFU) } & Mannheimia haemolytica & 1 & 0.41 \\
\hline & Pasteurella multocida & 1 & 0.06 \\
\hline & Histophillus somni & 0.1 & 0.26 \\
\hline & Trueperella pyogenes & 100 & 2.06 \\
\hline & Mycoplasma bovis & 1 & 1.42 \\
\hline \multirow[t]{5}{*}{ Synthesized DNA (copies) } & Bovine coronavirus & 10 & 1.34 \\
\hline & Influenza D virus & 10 & 0.25 \\
\hline & Bovine rhinitis $B$ virus & 100 & 0.89 \\
\hline & Bovine adenovirus 3 & 10 & 0.99 \\
\hline & Ureaplasma diversum & 10 & 1.62 \\
\hline
\end{tabular}

LOD: Limit of detection; $\mathrm{CV}$ : Coefficient of variation.

M. bovis strain Donetta were obtained from the National Veterinary Assay Laboratory in Japan. The BVDV strain Nose (bovine / Japan/1974) and BHV-1 strain Ishikawa (bovine /Japan/1988) used in this study were isolated from field samples. To evaluate the primer-probe sets targeting $\mathrm{BCoV}, \mathrm{IDV}, \mathrm{BRBV}, \mathrm{BAdV} 3$ and $U$. diversum, synthesized DNA (Integrated DNA Technologies, Inc.) was used instead of nucleic acids extracted from infectious pathogens, because these pathogens were unavailable. Nucleic acids from the $10 \%$ swab emulsion and pathogens $\left(1.0 \times 10^{5} \mathrm{TCID}_{50} / \mathrm{m} l\right.$ or $\left.\mathrm{CFU} / \mathrm{m} l\right)$ were extracted as described above. Then, 10 -fold serial dilutions of the extracted nucleic acids or synthesized DNA were spiked into the eluates of negative nasal swabs. The final concentrations were adjusted to the following: pathogen DNA or RNA, $1.0 \times 10^{-1}$ to $1.0 \times 10^{2} \mathrm{TCID}_{50} /$ reaction or CFU/reaction; and synthesized DNA, $1.0 \times 10^{\circ}$ to $10^{3}$ copies/reaction. The tests were performed in duplicate using separate serial dilutions. The LOD was determined, and reproducibility was evaluated using the coefficient of variation $(\mathrm{CV})$ calculated from the quantification cycle $(\mathrm{Cq})$.

\section{Dembo respiratory-PCR assay of clinical samples}

The assay was applied to test clinical samples; we also evaluated the diagnostic performance of the assay. A total of 40 samples of bovine nasal swabs were collected in 2015 from six farms (farms A-F) in which BRDC pathogens presences were identified in Gifu Central Livestock Hygiene Service Center. Information of individual cattle were indicated in Supplemental Table 2. Nucleic acids extracted from samples were tested in triplicated with Dembo-PCR [31]. Samples were determined positive, if the Cq values were calculated by the algorithm described above in more than two of three run.

\section{RESULTS}

\section{Sensitivity, linearity and efficiency evaluated with standard curves from synthesized DNA}

To evaluate the sensitivity, linearity and efficiency of the PCR, 10-fold serial dilutions of synthesized DNA were tested by realtime PCR. Standard curves were constructed from Cq values, and then, the LOD, $\mathrm{R}^{2}$ and E were evaluated (Fig. S1). For BVDV, BHV-1 and BAdV 7, standard curves have already been evaluated under the same conditions in a previous study [31]. The LOD, based on DNA copy number, was $\leq 100$ copies/reaction for all primer-probe sets. In addition, the calibration curves of all assays covered a linear dynamic range of more than five orders of magnitude and showed $\mathrm{R}^{2}$ values of at least 0.9818 . PCR efficiencies were in the range of $84.2-101.8 \%$.

\section{Sensitivity and reproducibility tests using nasal swab samples}

The LOD, taking into account possible PCR inhibition by components of nasal swab samples, and CV values, used to evaluate inter-assay error, are described in Table 2. Except for that of BPIV-3, all LODs were $\leq 10 \mathrm{TCID}_{50} /$ reaction for extracted nasal swabs spiked with viral nucleic acids. For bacterial nucleic acids, the LOD of the assay for all bacteria other than $T$. pyogenes was $\leq 1 \mathrm{CFU} /$ reaction. The LOD of $T$. pyogenes was higher than those for other bacteria. For the synthesized DNA, because the pathogens were not available, an LOD of $\leq 100$ copies/reaction was also obtained in each assay. CV values were at most $2.25 \%$; this reproducibility was observed with BPIV-3 testing. 
Table 3. Result of Dembo respiratory-PCR using clinical samples

\begin{tabular}{|c|c|c|c|c|c|c|c|}
\hline \multirow[b]{2}{*}{ Pathogens } & \multicolumn{7}{|c|}{ Positive samples in Dembo respiratory-PCR } \\
\hline & $\begin{array}{c}\text { Farm A } \\
\mathrm{N}=8 \\
\mathrm{n}(\%)\end{array}$ & $\begin{array}{c}\text { Farm B } \\
\mathrm{N}=6 \\
\mathrm{n}(\%)\end{array}$ & $\begin{array}{c}\text { Farm C } \\
\mathrm{N}=4 \\
\mathrm{n}(\%)\end{array}$ & $\begin{array}{c}\text { Farm D } \\
\mathrm{N}=5 \\
\mathrm{n}(\%)\end{array}$ & $\begin{array}{c}\text { Farm E } \\
\mathrm{N}=7 \\
\mathrm{n}(\%)\end{array}$ & $\begin{array}{c}\text { Farm F } \\
\mathrm{N}=10 \\
\mathrm{n}(\%)\end{array}$ & $\begin{array}{l}\text { Total } \\
\mathrm{N}=40 \\
\mathrm{n}(\%)\end{array}$ \\
\hline Bovine viral diarrheal virus & - & $1(16.7)$ & - & - & - & - & $1(2.5)$ \\
\hline Bovine coronavirus & - & $5(83.3)$ & - & $5(100)$ & - & - & $10(25.0)$ \\
\hline Bovine parainfluenza virus 3 & - & - & - & - & - & - & - \\
\hline Bovine respiratory syncytial virus & $7(85.7)$ & $1(16.7)$ & - & - & $5(71.4)$ & $10(100)$ & $23(56.4)$ \\
\hline Influenza $\mathrm{D}$ virus & - & - & - & - & - & - & - \\
\hline Bovine rhinitis A virus & - & - & - & - & - & - & - \\
\hline Bovine rhinitis B virus & - & $4(66.7)$ & - & $1(20.0)$ & $6(85.7)$ & - & $11(27.5)$ \\
\hline Bovine herpesvirus 1 & - & - & - & - & - & - & - \\
\hline Bovine adenovirus 3 & - & - & - & - & - & - & - \\
\hline Bovine adenovirus 7 & - & - & - & - & - & - & - \\
\hline Mannheimia haemolytica & $2(25.0)$ & $4(66.7)$ & $2(50.0)$ & $3(60.0)$ & - & $1(10.0)$ & $12(30.0)$ \\
\hline Pasteurella multocida & $8(100)$ & $6(100)$ & $4(100)$ & $5(100)$ & - & - & $23(57.5)$ \\
\hline Histophillus somni & $4(50.0)$ & $5(83.3)$ & $4(100)$ & $4(80.0)$ & - & $1(10.0)$ & $18(45.0)$ \\
\hline Trueperella pyogenes & - & - & $3(75.0)$ & $2(40.0)$ & $1(14.3)$ & $1(10.0)$ & $7(17.5)$ \\
\hline Mycoplasma bovis & $6(75.0)$ & $5(83.3)$ & $4(100)$ & $5(100)$ & - & - & $20(50.0)$ \\
\hline Ureaplasma diversum & $6(75.0)$ & $5(83.3)$ & $4(100)$ & $4(80.0)$ & $2(28.6)$ & $2(20.0)$ & $24(60.0)$ \\
\hline
\end{tabular}

\section{Dembo respiratory-PCR performance in clinical sample testing}

A total of 40 nasal swabs from different affected animals on six farms with BRDC outbreaks were applied to Dembo respiratoryPCR. The results are presented as the number and percentage of positive samples from each farm (Table 3). In samples from farm A, both viral and bacterial pathogens, including BRSV (85.7\%), P. multocida (100\%), M. bovis (75\%) and U. diversum (75\%), were detected at high frequency, whereas mainly viral pathogens, including BRSV $(71.4 \%)$ and BRBV $(85.7 \%)$ in farm E and BRSV (100\%) in farm F, were prevailed. In samples from farms B and D, mixed infections of BCoV $(83.3 \%$ and $100 \%)$ and bacterial pathogens were detected. The results of tests of individual cattle are shown in Supplemental Table 2.

\section{DISCUSSION}

In this study, Dembo respiratory-PCR was developed, following the methods applied for Dembo diarrhea-PCR described in a previous report [31]. Since all primer-probe sets were optimized in the same temperature conditions, Dembo respiratory-PCR can detect a total of 16 pathogens, including 10 viruses and six bacteria, in a single run of TaqMan real-time PCR. Notably, we designed primers for IDV, BRAV and BRBV, which are not traditionally tested in Japan as etiologic agents of BRDC. IDV was first found in pigs and then from cattle, showing a significant association with BRDC [14, 23]. An assay to detect IDV by TaqMan real-time PCR has already been reported [15]. However, new IDV strains were recently identified [4-6, 19], and the nucleic acid sequences of some strains have mismatches to the reported primer-probe set. To address this issue, a new primer-probe set was designed in this study. Nevertheless, forward primer has a few mismatches to the sequence of D/bovine/Ibaraki/7768/2016, which was identified very recently, and the primer is needed for further improvement. BRAV and BRBV have been commonly found in cattle with BRDC in the United States [13]. BRBV was detected from BRDC cattle also in this study, but a previous study suggested that BRBV was not significantly associated with BRDC [23]. The importance of BRBV in BRDC remains uncertain. IDV and BRAV were undetected in the clinical samples in this study. In sensitivity test, all assays showed low LOD $(\leq 100 \mathrm{CFU}$, $\mathrm{TCID}_{50}$ or copies/reaction). The LOD of BPIV-3 was higher than other virus (100 $\mathrm{TCID}_{50} /$ reaction), but a previous study showed a similar level of sensitivity [18]. Dembo respiratory-PCR can be performed to detect pathogens that are currently considered to be associated with BRDC.

By Dembo respiratory-PCR, multiple BRDC pathogens that infect cattle can be detected comprehensively and simultaneously. The Dembo respiratory-PCR can quickly elucidate combinations of pathogen in a sample. Notably, in one BVDV-positive sample, $\mathrm{BCoV}, \mathrm{BRSV}$ and bacterial pathogens were also detected. A previous study indicated that BRSV infection diminished the host's clearance ability in the upper respiratory tract or altered the immune response $[9,10]$, possibly facilitating bacterial opportunistic infections, whereas an experimental study showed that infection with BRSV infection alone resulted in clinical signs and lesions in lung tissue [10]. As well as BRSV, BCoV generally impairs mucosal immunity in the upper respiratory tract [27]. In this way, the Dembo respiratory-PCR helps revealing the infection of multiple pathogens at once. For the same purpose, multiplex PCRs that can detect utmost three pathogens were developed in the previous studies $[18,30]$. However, multiplex PCR has the restriction on target number and the risk that primer-probe sets interfere in each other.

Compared with one assay-one pathogen test, Dembo respiratory-PCR can identified a wide range of existing pathogens quickly 
and easily. Considering multiple etiology of BRDC, screening by Dembo respiratory-PCR would help determining treatment and prevention measures. This detection system may provide an alternative testing method that is simpler, earlier and more comprehensive than existing assays.

ACKNOWLEDGMENTS. This work was supported by the Research Project for Improving Food Safety and Animal Health of the Ministry of Agriculture, Forestry and Fisheries of Japan. The authors declare no conflict of interest associated with this manuscript.

\section{REFERENCES}

1. Allen, J. W., Viel, L., Bateman, K. G. and Rosendal, S. 1992. Changes in the bacterial flora of the upper and lower respiratory tracts and bronchoalveolar lavage differential cell counts in feedlot calves treated for respiratory diseases. Can. J. Vet. Res. 56: 177-183. [Medline]

2. Boxus, M., Letellier, C. and Kerkhofs, P. 2005. Real Time RT-PCR for the detection and quantitation of bovine respiratory syncytial virus. J. Virol. Methods 125: 125-130. [Medline] [CrossRef]

3. Bustin, S. A., Benes, V., Garson, J. A., Hellemans, J., Huggett, J., Kubista, M., Mueller, R., Nolan, T., Pfaffl, M. W., Shipley, G. L., Vandesompele, J. and Wittwer, C. T. 2009. The MIQE guidelines: minimum information for publication of quantitative real-time PCR experiments. Clin. Chem. 55: 611-622. [Medline] [CrossRef]

4. Chiapponi, C., Faccini, S., De Mattia, A., Baioni, L., Barbieri, I., Rosignoli, C., Nigrelli, A. and Foni, E. 2016. Detection of influenza D virus among swine and cattle, Italy. Emerg. Infect. Dis. 22: 352-354. [Medline] [CrossRef]

5. Collin, E. A., Sheng, Z., Lang, Y., Ma, W., Hause, B. M. and Li, F. 2015. Cocirculation of two distinct genetic and antigenic lineages of proposed influenza D virus in cattle. J. Virol. 89: 1036-1042. [Medline] [CrossRef]

6. Ferguson, L., Eckard, L., Epperson, W. B., Long, L. P., Smith, D., Huston, C., Genova, S., Webby, R. and Wan, X. F. 2015. Influenza D virus infection in Mississippi beef cattle. Virology 486: 28-34. [Medline] [CrossRef]

7. Fulton, R. W. and Confer, A. W. 2012. Laboratory test descriptions for bovine respiratory disease diagnosis and their strengths and weaknesses: gold standards for diagnosis, do they exist? Can. Vet. J. 53: 754-761. [Medline]

8. Gagea, M. I., Bateman, K. G., van Dreumel, T., McEwen, B. J., Carman, S., Archambault, M., Shanahan, R. A. and Caswell, J. L. 2006. Diseases and pathogens associated with mortality in Ontario beef feedlots. J. Vet. Diagn. Invest. 18: 18-28. [Medline] [CrossRef]

9. Gershwin, L. J., Gunther, R. A., Hornof, W. J. and Larson, R. F. 2008. Effect of infection with bovine respiratory syncytial virus on pulmonary clearance of an inhaled antigen in calves. Am. J. Vet. Res. 69: 416-422. [Medline] [CrossRef]

10. Gershwin, L. J., Van Eenennaam, A. L., Anderson, M. L., McEligot, H. A., Shao, M. X., Toaff-Rosenstein, R., Taylor, J. F., Neibergs, H. L., Womack J., Bovine Respiratory Disease Complex Coordinated Agricultural Project Research Team. 2015. Single pathogen challenge with agents of the bovine respiratory disease complex. PLOS ONE 10: e0142479. [Medline] [CrossRef]

11. Griffin, D., Chengappa, M. M., Kuszak, J. and McVey, D. S. 2010. Bacterial pathogens of the bovine respiratory disease complex. Vet. Clin. North Am. Food Anim. Pract. 26: 381-394. [Medline] [CrossRef]

12. Härtel, H., Nikunen, S., Neuvonen, E., Tanskanen, R., Kivelä, S. L., Aho, R., Soveri, T. and Saloniemi, H. 2004. Viral and bacterial pathogens in bovine respiratory disease in Finland. Acta Vet. Scand. 45: 193-200. [Medline] [CrossRef]

13. Hause, B. M., Collin, E. A., Anderson, J., Hesse, R. A. and Anderson, G. 2015. Bovine rhinitis viruses are common in U.S. cattle with bovine respiratory disease. PLOS ONE 10: e0121998. [Medline] [CrossRef]

14. Hause, B. M., Collin, E. A., Liu, R., Huang, B., Sheng, Z., Lu, W., Wang, D., Nelson, E. A. and Li, F. 2014. Characterization of a novel influenza virus in cattle and Swine: proposal for a new genus in the Orthomyxoviridae family. MBio 5: e00031-e14. [Medline] [CrossRef]

15. Hause, B. M., Ducatez, M., Collin, E. A., Ran, Z., Liu, R., Sheng, Z., Armien, A., Kaplan, B., Chakravarty, S., Hoppe, A. D., Webby, R. J., Simonson, R. R. and Li, F. 2013. Isolation of a novel swine influenza virus from Oklahoma in 2011 which is distantly related to human influenza C viruses. PLoS Pathog. 9: e1003176. [Medline] [CrossRef]

16. Hilton, W. M. 2014. BRD in 2014: where have we been, where are we now, and where do we want to go? Anim. Health Res. Rev. 15: 120-122. [Medline] [CrossRef]

17. Hodgson, P. D., Aich, P., Stookey, J., Popowych, Y., Potter, A., Babiuk, L. and Griebel, P. J. 2012. Stress significantly increases mortality following a secondary bacterial respiratory infection. Vet. Res. (Faisalabad) 43: 21. [Medline] [CrossRef]

18. Horwood, P. F. and Mahony, T. J. 2011. Multiplex real-time RT-PCR detection of three viruses associated with the bovine respiratory disease complex. J. Virol. Methods 171: 360-363. [Medline] [CrossRef]

19. Jiang, W. M., Wang, S. C., Peng, C., Yu, J. M., Zhuang, Q. Y., Hou, G. Y., Liu, S., Li, J. P. and Chen, J. M. 2014. Identification of a potential novel type of influenza virus in Bovine in China. Virus Genes 49: 493-496. [Medline] [CrossRef]

20. Mahlum, C. E., Haugerud, S., Shivers, J. L., Rossow, K. D., Goyal, S. M., Collins, J. E. and Faaberg, K. S. 2002. Detection of bovine viral diarrhea virus by TaqMan reverse transcription polymerase chain reaction. J. Vet. Diagn. Invest. 14: 120-125. [Medline] [CrossRef]

21. Marques, L. M., Amorim, A. T., Martins, H. B., Rezende, I. S., Barbosa, M. S., Lobão, T. N., Campos, G. B. and Timenetsky, J. 2013. A quantitative TaqMan PCR assay for the detection of Ureaplasma diversum. Vet. Microbiol. 167: 670-674. [Medline] [CrossRef]

22. Miles, D. G. 2009. Overview of the North American beef cattle industry and the incidence of bovine respiratory disease (BRD). Anim. Health Res. Rev. 10: 101-103. [Medline] [CrossRef]

23. Ng, T. F. F., Kondov, N. O., Deng, X., Van Eenennaam, A., Neibergs, H. L. and Delwart, E. 2015. A metagenomics and case-control study to identify viruses associated with bovine respiratory disease. J. Virol. 89: 5340-5349. [Medline] [CrossRef]

24. Nolan, T., Hands, R. E., Ogunkolade, W. and Bustin, S. A. 2006. SPUD: a quantitative PCR assay for the detection of inhibitors in nucleic acid preparations. Anal. Biochem. 351: 308-310. [Medline] [CrossRef]

25. Perkins, G. A., Goodman, L. B., Dubovi, E. J., Kim, S. G. and Osterrieder, N. 2008. Detection of equine herpesvirus-1 in nasal swabs of horses by quantitative real-time PCR. J. Vet. Intern. Med. 22: 1234-1238. [Medline] [CrossRef]

26. Sachse, K., Salam, H. S. H., Diller, R., Schubert, E., Hoffmann, B. and Hotzel, H. 2010. Use of a novel real-time PCR technique to monitor and quantitate Mycoplasma bovis infection in cattle herds with mastitis and respiratory disease. Vet. J. 186: 299-303. [Medline] [CrossRef]

27. Saif, L. J. 2010. Bovine respiratory coronavirus. Vet. Clin. North Am. Food Anim. Pract. 26: 349-364. [Medline] [CrossRef]

28. Taylor, J. D., Fulton, R. W., Lehenbauer, T. W., Step, D. L. and Confer, A. W. 2010a. The epidemiology of bovine respiratory disease: What is the evidence for predisposing factors? Can. Vet. J. 51: 1095-1102. [Medline] 
29. Taylor, J. D., Fulton, R. W., Lehenbauer, T. W., Step, D. L. and Confer, A. W. 2010b. The epidemiology of bovine respiratory disease: what is the evidence for preventive measures? Can. Vet. J. 51: 1351-1359. [Medline]

30. Thonur, L., Maley, M., Gilray, J., Crook, T., Laming, E., Turnbull, D., Nath, M. and Willoughby, K. 2012. One-step multiplex real time RT-PCR for the detection of bovine respiratory syncytial virus, bovine herpesvirus 1 and bovine parainfluenza virus 3. BMC Vet. Res. 8: 37. [Medline] [CrossRef]

31. Tsuchiaka, S., Masuda, T., Sugimura, S., Kobayashi, S., Komatsu, N., Nagai, M., Omatsu, T., Furuya, T., Oba, M., Katayama, Y., Kanda, S., Yokoyama, T. and Mizutani, T. 2016. Development of a novel detection system for microbes from bovine diarrhea by real-time PCR. J. Vet. Med. Sci. 78: 383-389. [Medline] [CrossRef]

32. Wernike, K., Hoffmann, B., Kalthoff, D., König, P. and Beer, M. 2011. Development and validation of a triplex real-time PCR assay for the rapid detection and differentiation of wild-type and glycoprotein E-deleted vaccine strains of Bovine herpesvirus type 1. J. Virol. Methods 174: 77-84. [Medline] [CrossRef]

33. Wong, K. and Xagoraraki, I. 2010. Quantitative PCR assays to survey the bovine adenovirus levels in environmental samples. J. Appl. Microbiol. 109: 605-612. [Medline] 